\title{
Trend in research publications of Botanical Survey of India during 2001-2015
}

\author{
Manohar Pathak ${ }^{1}$, Asutosh Kumar Verma², S. S. Dash ${ }^{3}$, P. Singh ${ }^{3}$ and Kumar Avinash Bharati ${ }^{4 * \mathbb{}}$ \\ ${ }^{1}$ CSIR-National Institute of Science Communication and Information Resources, New Delhi - 110012. \\ 2Botanical Survey of India, Central Regional Centre, Allahabad - 211002. \\ ${ }^{3}$ Botanical Survey of India, Salt lake City, Kolkata - 700064. \\ ${ }^{4}$ Central National Herbarium, Botanical Survey of India, Howrah - 711103. \\ 凶Corresponding author: k.avinash@hotmail.com

\section{भारतीय वनस्पति सर्वेक्षण द्वारा प्रकाशित शोध प्रकाशनों की प्रवृत्ति: $2001-2015$}

\author{
मनोहर पाठक, आशुतोष कुमार वर्मा, एस. एस. दाश, पी. सिंह एवं कुमार अविनाश भारती
}

\section{सारांश}

यह शोध पत्र भारतीय वनस्पति सर्वेक्षण के द्वारा 2001 से 2015 के दौरान प्रकाशित शोध प्रकाशनों की वृद्धिदर की गणना प्रस्तुत करता है जिसके लिये अंकात्मक मापन किया गया है। आंकड़ों के अध्ययन के लिये "स्कोपस डाटाबेस" का उपयोग कर आंकलन किया गया है, जिससे निष्कर्ष निकलता है कि अध्ययन काल के दौरान कुल 613 शोध पत्रों का प्रकाशन हुआ है। इस आंकलन से यह भी निष्कर्ष निकलता है कि प्रकाशन में लगातार उत्तरोत्तर वृद्धि हुई है, जो 2001 में 7 थी वह 2015 में बढ़कर 95 तक पहुँच गई, अर्थात 13 गुणा वृद्धि दर्ज की गई ।

\begin{abstract}
The present communication measures the growth of research publication of Botanical Survey of India during the period 2001-2015 using bibliometric tools. The data were drawn from the Scopus database and analyzed, which revealed that a total of 613 papers were published during the said period. This analysis also shows that, there is an incremental growth in the number of publications from 7 papers in 2001 to 95 papers in 2015 which is significantly thirteen-fold progress.
\end{abstract}

Keywords: Bibliometric, Publication, Mapping, Taxonomy, Botanical Survey of India

\section{INTRODUCTION}

The Botanical Survey of India (BSI), a premier research organization of the country established in 1890 , serves the nation by providing scientific basis for conservation and sustainable use of wild plant diversity through survey, documentation, taxonomic research and environmental awareness. (http://bsi.gov.in/)

The reorganization of Botanical Survey of India in 1954 revived the taxonomic research in India. A series of the taxonomic, floristic, monographic studies on the Indian flora as well as many representative, fragile ecosystems, protected areas, etc., were carried out by its scientists. These activities have significantly added to our knowledge on plant diversity of India. Many new species have been described; florist accounts of many inaccessible regions have published in additions to the many more new additions to the present geographical limits of our country. However, in absence of any appraisal of its huge work and services rendered, it sometimes impossible to correlate all 
the scattered information accumulated over the century. Therefore, in the present communication an attempt has been made for an assessment and appraisal of the research publication of the organization during 2001-15.

It is pertinent to say that the economy is shifting from resource base to knowledge base because scientific and technological knowledge materialized in new equipments and new products (Adler, 2001). As a result research becomes more and more global, multidisciplinary and collaborative in nature; in such scenario personal knowledge and experience are not sufficient to measure and understand the research productivity (Pendlebury, 2010). Keeping in view, identifying organization's specific areas of focus and strength as well as weakness and contributions of organization should be highlighted. A quantitative study was performed to track, analyze and visualize research productivity of BSI during the last one and half decade.

\section{METHODOLOGY}

The data analyzed here have drawn from the Scopus database. It is the largest database of peer-reviewed literature such as scientific periodicals, proceedings and books. The temporal coverage is 1996 to present, having more than 62 million records of the database, 1.2 billion references and 22,000 titles (https://www.scopus. $\mathrm{com} /$ ). The key word Botanical Survey of India in the field 'Affiliation' was used to retrieve the data. The data were downloaded in excel file for further analysis. The data were compiled, analyzed and interpreted to know the growth of research publications, productive authors, status of national and international collaboration, focus on the interdisciplinary study and the preference of journals on the taxonomic research.

\section{RESULTS AND DISCUSSION}

Since last one and half decade thirteen-fold increase in publications was observed. During 2001, the organization had published only seven papers, however, since 2005 onwards there is a gradual increase in publications, except in the year 2011. The growth in quantity is intense since 2012 (Fig. 1). Between 2001 and 2015, a total of 613 papers have been published, including seven chapters in the edited books. Between 2011

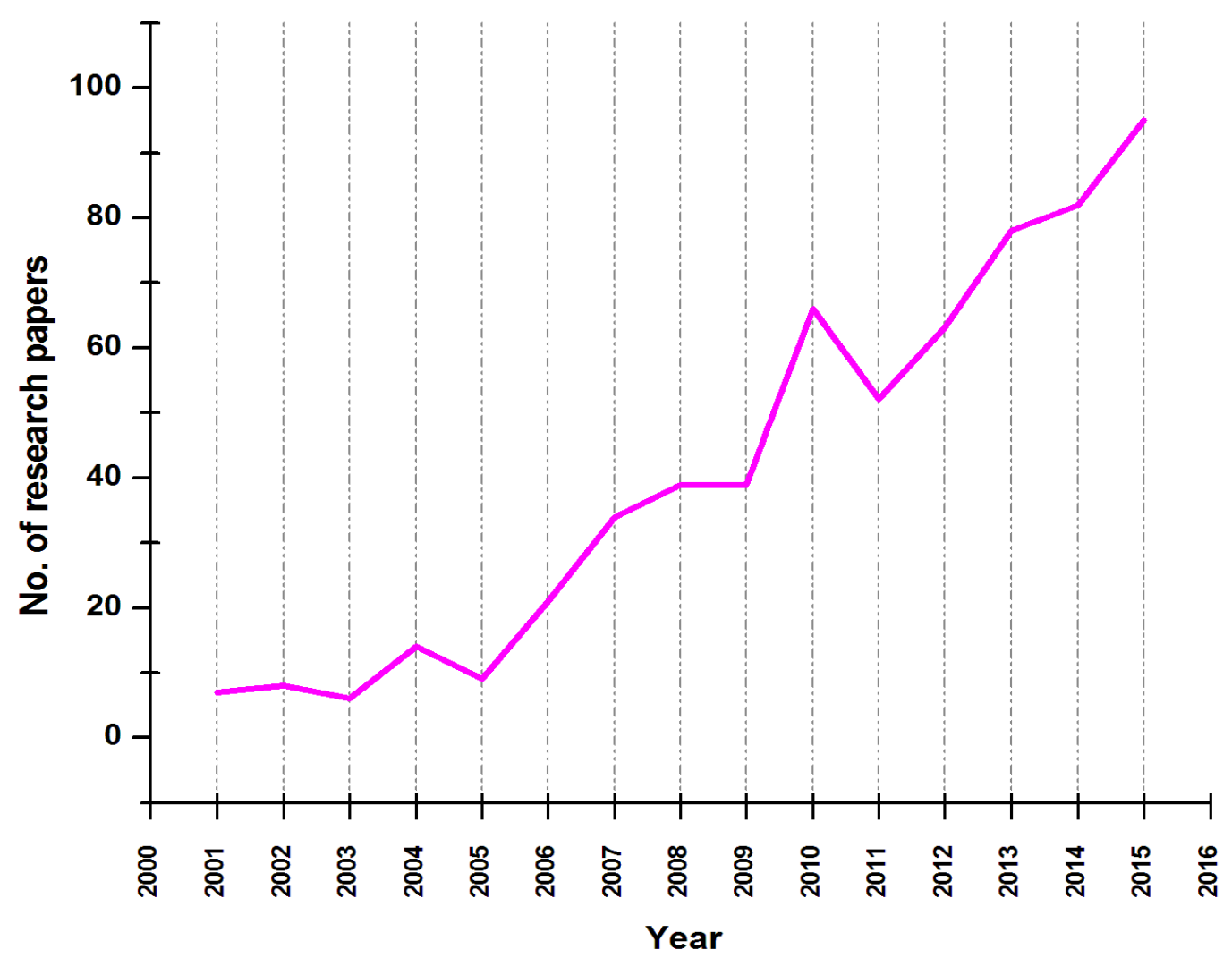

Fig. 1: Trend in publications of scientists of Botanical Survey of India in the past 15 years 
Table 1. Distribution of publications in different subject categories.

\begin{tabular}{|c|c|c|c|c|c|c|c|}
\hline \multicolumn{2}{|c|}{ 2001-2005 } & \multicolumn{2}{|c|}{$2006-2010$} & \multicolumn{2}{|c|}{ 2011-2015 } & \multicolumn{2}{|c|}{ 2001-15 } \\
\hline Category & Count & Category & Count & Category & Count & Total & Share (\%) \\
\hline Angiosperm & 18 & Angiosperm & 97 & Angiosperm & 229 & 344 & 56.11 \\
\hline Gymnosperm & - & Gymnosperm & 02 & Gymnosperm & - & 02 & 0.32 \\
\hline Pteridophyte & 01 & Pteridophyte & 04 & Pteridophyte & 05 & 10 & 1.63 \\
\hline Bryophyte & 01 & Bryophyte & 17 & Bryophyte & 19 & 37 & 6.03 \\
\hline Algae & 01 & Algae & 03 & Algae & 03 & 07 & 1.14 \\
\hline Fungi & 07 & Fungi & 04 & Fungi & 20 & 31 & 5.05 \\
\hline Lichen & 05 & Lichen & 13 & Lichen & 14 & 32 & 5.22 \\
\hline Ethnobotany & 01 & Ethnobotany & 19 & Ethnobotany & 21 & 41 & 6.68 \\
\hline Multidisciplinary & 10 & Multidisciplinary & 40 & Multidisciplinary & 59 & 109 & 17.78 \\
\hline Total & 44 & Total & 199 & Total & 370 & 613 & \\
\hline
\end{tabular}

and 2015, 1.8 times growth in research publications has been observed in comparison to 2006 and 2010. A total of 370 research papers were published during 2011-15, as compared to 199 articles in between 2006 and 2010 and 44 articles in between 2001 and 2005. It shows that publications have made in almost all the subject areas but the few areas such as angiosperms and cryptogams have taken quantum jump. All India Co-ordinated Projects on Taxonomy (AICOPTAX) has given an impetus to the research program in Botanical Survey of India. Many interior areas were thoroughly explored and surveyed, new discoveries have been described and reported. As a result, in previous five years (2011-2015) papers on fungi have been increased 5 times with compare to 2006-2010. Similarly, publications on angiosperm have been increased 2.36 times in past five years with compare to 2006-2010. This trend of increased publication in a particular field implies number of researchers engaged in the field, opportunities and preference of journals in publishing the findings of taxonomic research. Growth of 4.4 times in publication was observed during 2006-2010, as compare to 2001-2005. Table 1 suggests that during this period there has been an apparent increase in publication of the organization representing almost all the subject areas.

Table 3 shows international collaborations of scientists of BSI over the last one and half decade which is corroborated by number of collaborative papers. The tendency of getting citation is high for collaborative papers therefore researchers and policy makers believe
Table 2. The most preferred journals in which more than 20 articles were published

\begin{tabular}{llll}
\hline Rank & Name of the Journal & $\begin{array}{l}\text { Number of } \\
\text { Publications }\end{array}$ & $\begin{array}{l}\text { \% of } \\
\text { sharing }\end{array}$ \\
\hline 1. & Current Science & 70 & 18 \\
2. & Taiwania & 68 & 17 \\
3. & Rheedea & 53 & 13 \\
4. & Phytotaxa & 50 & 13 \\
5. & Journal of Japanese Botany & 34 & 9 \\
6. & Nordic Journal of Botany & 32 & 8 \\
7. & Kew Bulletin & 24 & 6 \\
8. & Taxon & 22 & 6 \\
9. & Mycotaxon & 21 & 5 \\
10. & Indian Journal of Tradi- & 21 & 5 \\
\hline
\end{tabular}

Table 3. Leading international research partners of BSI

\begin{tabular}{ll}
\hline Collaborative countries & Count \\
\hline United Kingdom & 24 \\
United States & 11 \\
Canada & 8 \\
Germany & 8 \\
Belgium & 7 \\
China & 7 \\
Australia & 5 \\
Netherlands & 5 \\
Finland & 4 \\
France & 4 \\
Nepal & 4 \\
Russian Federation & 4 \\
\hline
\end{tabular}


that collaboration is good (Kat \& Hiock, 1997). Out of 613 research papers, the BSI has published 130 papers with foreign collaboration. A total of 157 authors have contributed in 103 different journals (Table 2). Because of multidisciplinary in nature and encouraging of articles related to conservation and ecology Current Science is the most favored journal among all the publications. Rheedea is the second most preferred domestic journal for publication. The preferred overseas journals are Taiwania (18\%), Phytotaxa (13\%), and Journal of Japanese Botany (8\%). The growth of research in the organization is rapid and diverse and expected to grow further. However, the direction it takes in the future will equally significant.

\section{REFERENCES}

ADLER, P. S. 2001. Market, hierarchy, and trust: The knowledge economy and the future of capitalism. Organ. Sci. 12(2):215-234.

KAT, J. S. AND D. HIOCK. 1997. How much is a collaboration worth? A calibrated bibliometric mode. In Proceedings on the Sixth Conference of the International Society for Scientometric and Informetric, Jerusalem. pp 163-175.

PENDLEBURY, D. A. 2010. White paper: using bibliometrics in evaluating research, Thomson Reuters, Philadelphia, http://wokinfo.com/media/mtrp/UsingBibliometricsinEval_WP.pdf [accessed 22.07.2016]

http://bsi.gov.in/ The Botanical Survey of India. [accessed 22.07.2016]

https://www.scopus.com/ The Scopus database. [accessed 23.06.2016] 